\title{
DEVELOPMENT OF AN INFLATABLE AIRLOCK FOR DEEP SPACE EXPLORATION
}

\section{Douglas A. Litteken}

NASA Johnson Space Center

Thomas C. Jones

NASA Langley Research Center

AIAA SPACE Forum

Orlando, Florida

September 18, 2018 


\section{OUTLINE}

- Introduction

- History of Inflatable Airlock Development

- Design Considerations for Inflatable Airlocks

- Generic Airlock Considerations for Space Applications

- Inflatable Airlock Specific Considerations

- Conclusions and Future Work 


\section{OUTLINE}

- Introduction

- History of Inflatable Airlock Development

- Design Considerations for Inflatable Airlocks

- Generic Airlock Considerations for Space Applications

- Inflatable Airlock Specific Considerations

- Conclusions and Future Work 
- Airlocks have been used for EVAs (extravehicular activities) since 1965

- Airlock designs including integrated, single, and dual-chamber, along with various volumes and hatch shapes have been used

\begin{tabular}{|c|c|c|c|c|c|c|c|c|}
\hline \multicolumn{2}{|c|}{ In Service } & \multirow{2}{*}{ Name } & \multirow{2}{*}{$\begin{array}{c}\text { Type } \\
\text { /Chamber }\end{array}$} & \multirow{2}{*}{$\begin{array}{l}\text { Dimensions } \\
\text { L x D (ft) }\end{array}$} & \multirow{2}{*}{$\begin{array}{l}\text { Volume } \\
\qquad\left(\mathrm{ft}^{3}\right)\end{array}$} & \multirow{2}{*}{$\begin{array}{l}\text { Mass } \\
(\mathrm{lbm})\end{array}$} & \multicolumn{2}{|c|}{ EVA Hatch } \\
\hline From & To & & & & & & Shape & Opening (in) \\
\hline 1965 & 1965 & Voskhod 2 Volga & Inflatable & $8.2 \times 3.9$ & 88.3 & 551 & Circular & 26 \\
\hline 1965 & 1966 & Gemini Capsule & Integral & $19.0 \times 9.8$ & 90 & 8490 & Trapezoid & $15 \times 51 \times 37$ \\
\hline 1969 & 1972 & Apollo Ascent Module & Integral & $3.5 \times 7.7$ & 159 & 4740 & Square & $32 \times 32$ \\
\hline 1973 & 1974 & Skylab Airlock & Single & $12.8 \times 5.4$ & 322 & 16936 & Trapezoid & $15 \times 51 \times 37$ \\
\hline 1983 & 2011 & Shuttle Airlock & Single & $6.9 \times 5.3$ & 150 & 827 & D-Shape & 40 \\
\hline 1989 & 2001 & Mir Kvant Airlock & Single & $19.0 \times 13.1$ & 1413 & 21164 & Circular & 39 \\
\hline 2001 & Present & ISS Pirs Airlock & Single & $16.1 \times 8.4$ & 460 & 7892 & Circular & 39 \\
\hline 2001 & Present & ISS Quest Airlock & Dual & $18.0 \times 13.1$ & 1200 & 21896 & D-Shape & 40 \\
\hline
\end{tabular}


- Dual-chamber airlocks using an "Equipment Lock" and "Crew Lock" minimize the evacuated volume, separate the electronics and hardware, and provide redundancy in the event of a hatch failure

- While dual-chamber airlocks are recommended, they limit the launch volume available with a metallic structure design

- The use of an inflatable soft goods structure as a Crew Lock would provide valuable launch volume savings

- Inflatable soft goods have been studied since the 1950's as habitable space structures that offer large deployed volumes in a compact stowed launch package

- They utilize high strength fabrics and internal pressure to create a stiffened vessel that can replace traditional metallic or composite shell structures

- The soft goods shell is comparable in mass to a metallic vessel, but due to the packaged configuration, reduce the required launch volume and dynamics 


\section{OUTLINE}

- Introduction

- History of Inflatable Airlock Development

- Design Considerations for Inflatable Airlocks

- Generic Airlock Considerations for Space Applications

- Inflatable Airlock Specific Considerations

- Conclusions and Future Work 


\section{HISTORY OF INFLATABLE AIRLOCK DEVELOPMENT}

\section{Volga Inflatable Airlock - Voskhod 2}

- Developed by USSR in 1965

- Dimensions:

- Packed: $2.5 \mathrm{ft}$ long $x 3.9 \mathrm{ft}$ wide

- Expanded: $8.2 \mathrm{ft}$ long x $3.9 \mathrm{ft}$ wide; $88.3 \mathrm{ft}^{3}$ internal

- Hatch: 26 in diameter

- First ever EVA was conducted from the Volga airlock on the Voskhod 2 mission by Alexei Leonov in 1965

- Designed out of necessity because Voskhod capsule could not be depressurized

- Cylindrical in shape, utilized rubber air-booms around the circumference to maintain shape

- Airlock deployed nominally to 5.8 psia, used for a single crew member, and jettisoned after use

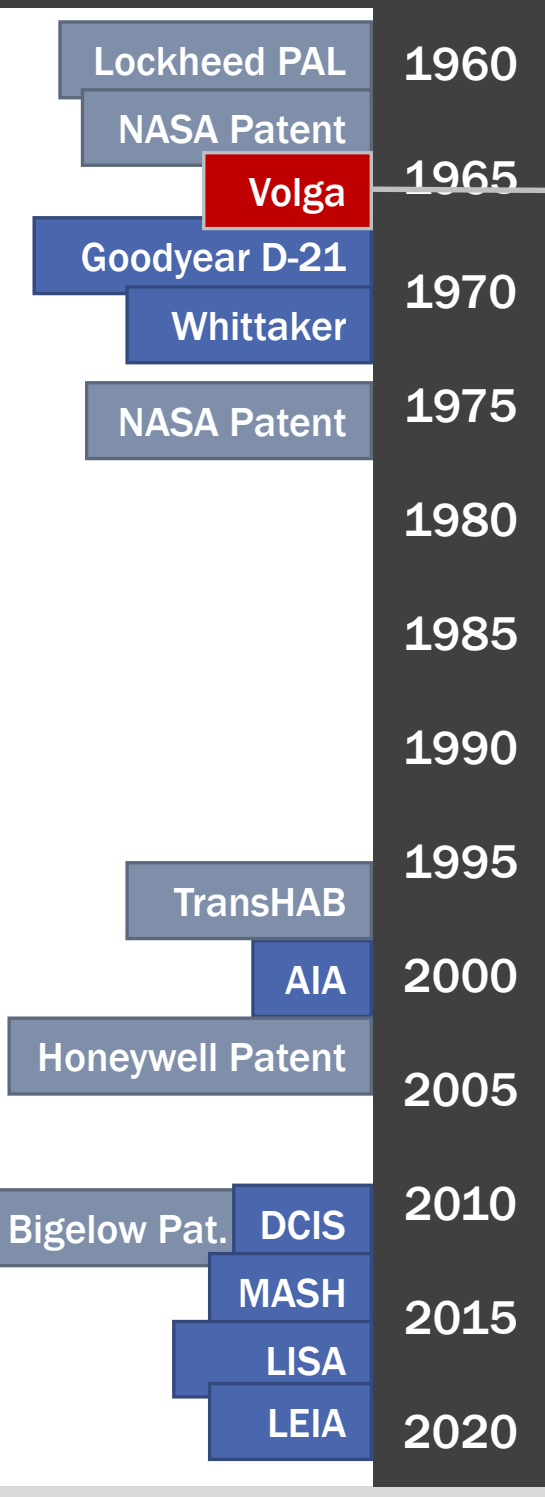




\section{HISTORY OF INFLATABLE AIRLOCK DEVELOPMENT}

\section{Volga Inflatable Airlock - Voskhod 2}
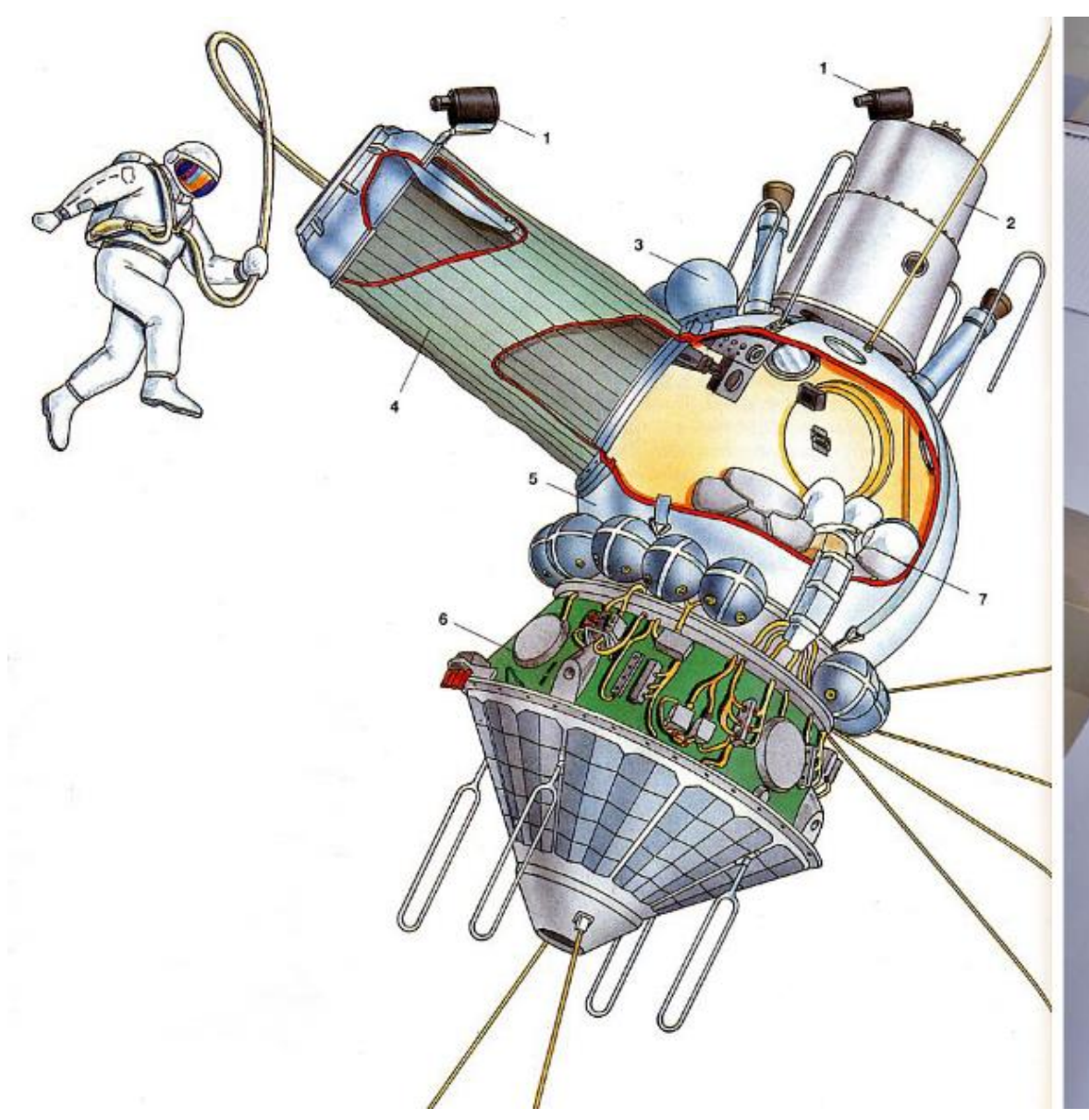

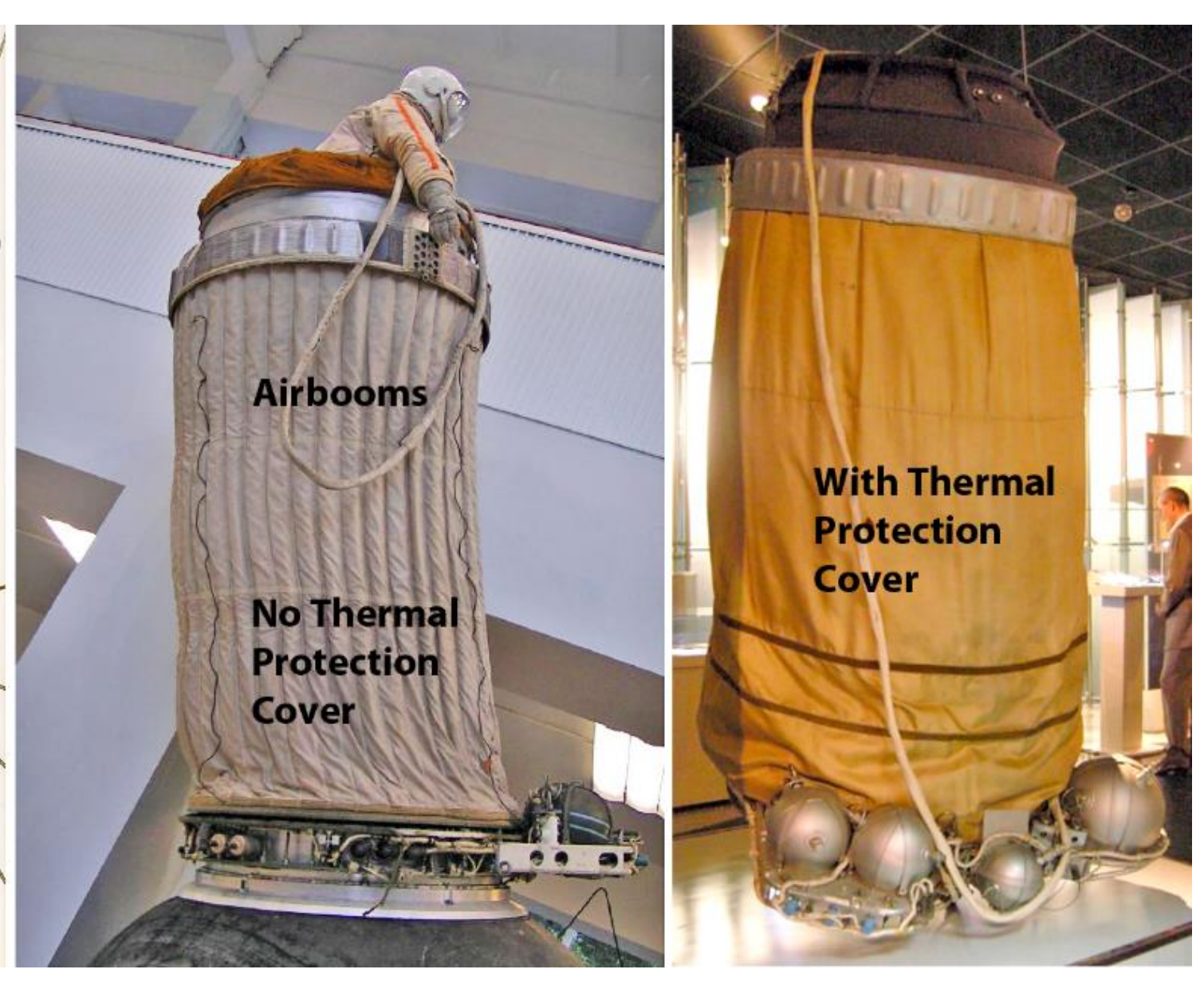

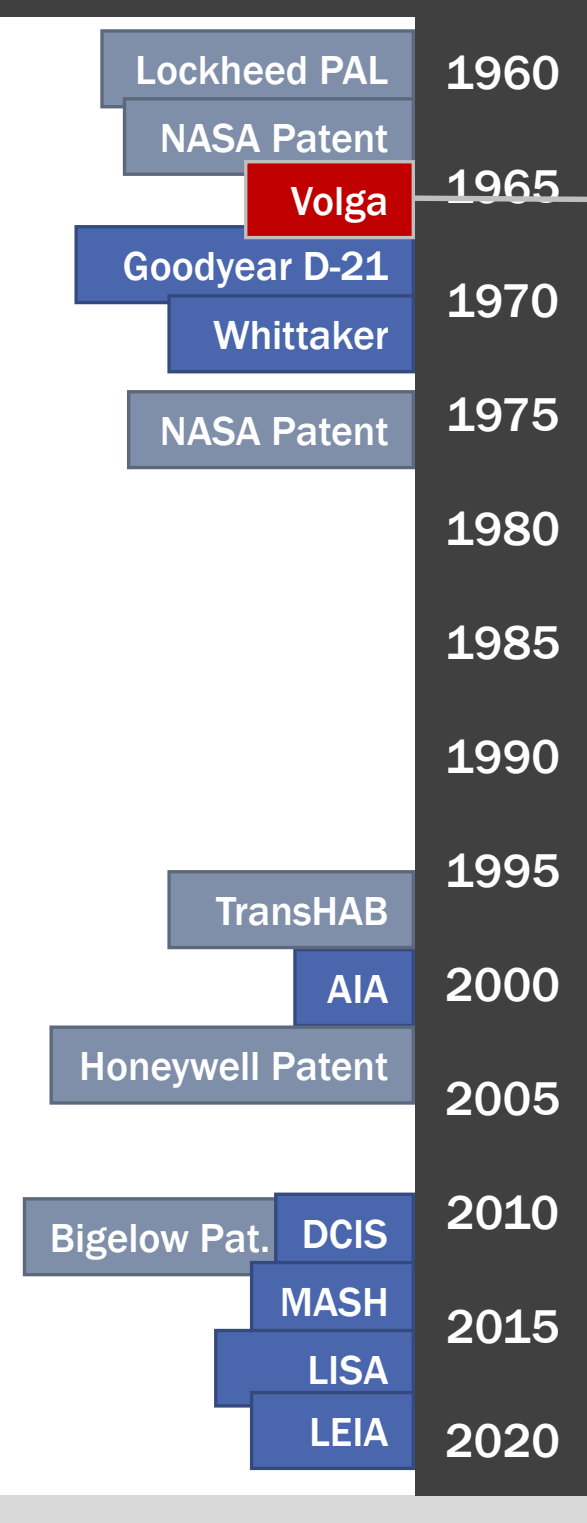




\section{HISTORY OF INFLATABLE AIRLOCK DEVELOPMENT}

\section{D-21 - Goodyear Inflatable Airlock}

- Built by Goodyear Aerospace Corporation in the 1960's

- Dimensions:

- Packed: $2.5 \mathrm{ft}$ long $x 4 \mathrm{ft}$ wide

- Expanded: $5.4 \mathrm{ft}$ long $x 5 \mathrm{ft}$ wide; $78 \mathrm{ft}^{3}$ internal

- Hatch: 34 in diameter

- Developed with Air Force and designed to fly on Skylab with a single crew member, but was dropped from mission suite

- Design pressure of 3.5 psia, made of nylon/foam/foil bladder, stainless steel/Taslan yarn, filament-wound structural layer, and polyurethane foam for MMOD (micrometeoroid and orbital debris) and thermal protection

- Extensive ground testing demonstrated structural capability and cold temperature deployment test proved the need for additional thermal protection layers and fire resistant materials

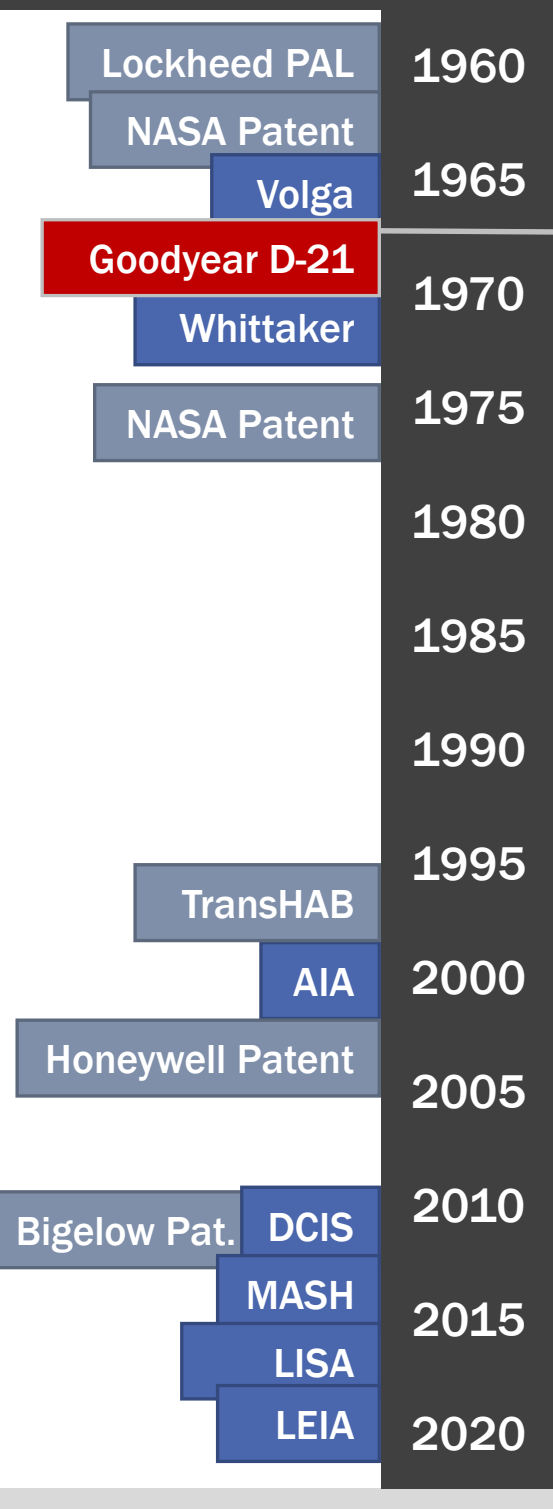




\section{HISTORY OF INFLATABLE AIRLOCK DEVELOPMENT}

\section{D-21 - Goodyear Inflatable Airlock}

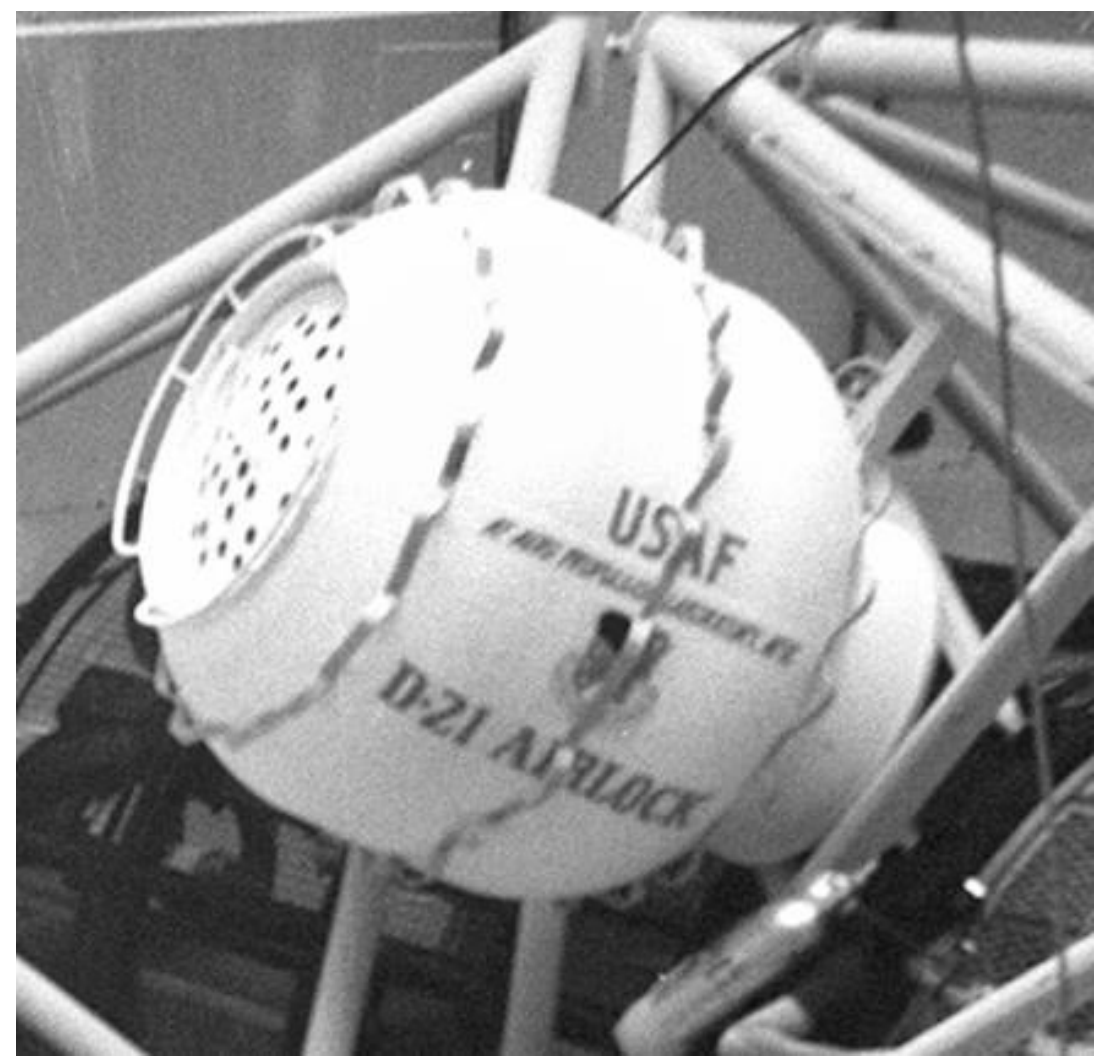

1960

1965
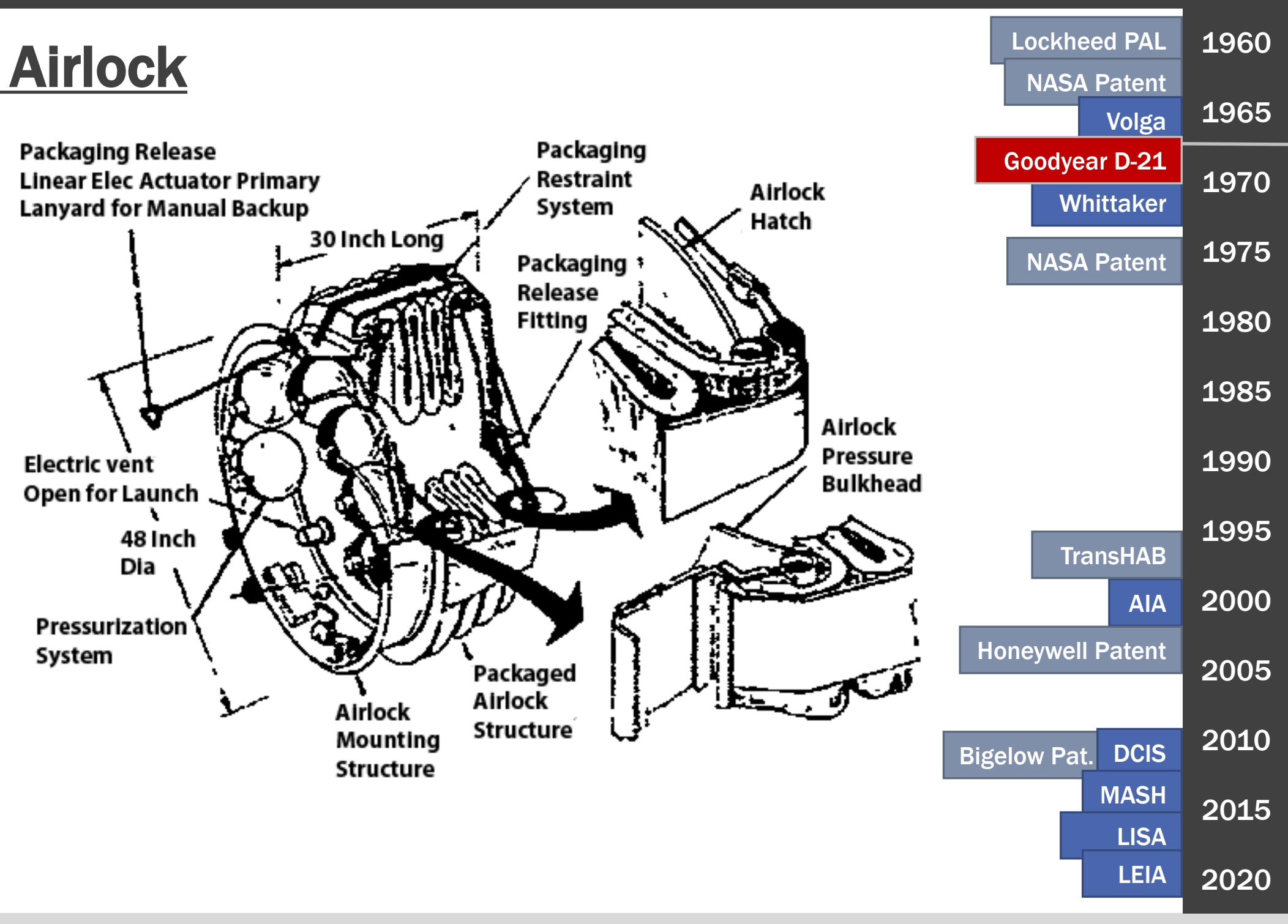

D. Litteken, NASA/JSC/ES2 | AIAA SPACE 2018 


\section{HISTORY OF INFLATABLE AIRLOCK DEVELOPMENT}

\section{Whittaker Inflatable Airlock}

- Developed by Whittaker Corporation in 1965

- Dimensions:

- Expanded: $7 \mathrm{ft}$ long $x \mathbf{4 t}$ wide; $87 \mathrm{ft}^{3}$ internal

- Hatch: 30 in diameter

- Developed under a research grant with NASA

- Design pressure of 10 psia, made of a thick vinyl bladder, isotensoid filamentary restraint layer in a knitted material, polyester foam for MMOD and an outer thermal coating for temperature control, sized for a single crew member

- Multiple design iterations were evaluated, including an inner airlock and packaging trials that identified the benefit of rigid (metallic) hoop bands in the structural shell to induce fold lines and resist loads
1960

Lockheed PAL

NASA Patent 


\section{HISTORY OF INFLATABLE AIRLOCK DEVELOPMENT}

\section{Whittaker Inflatable Airlock}
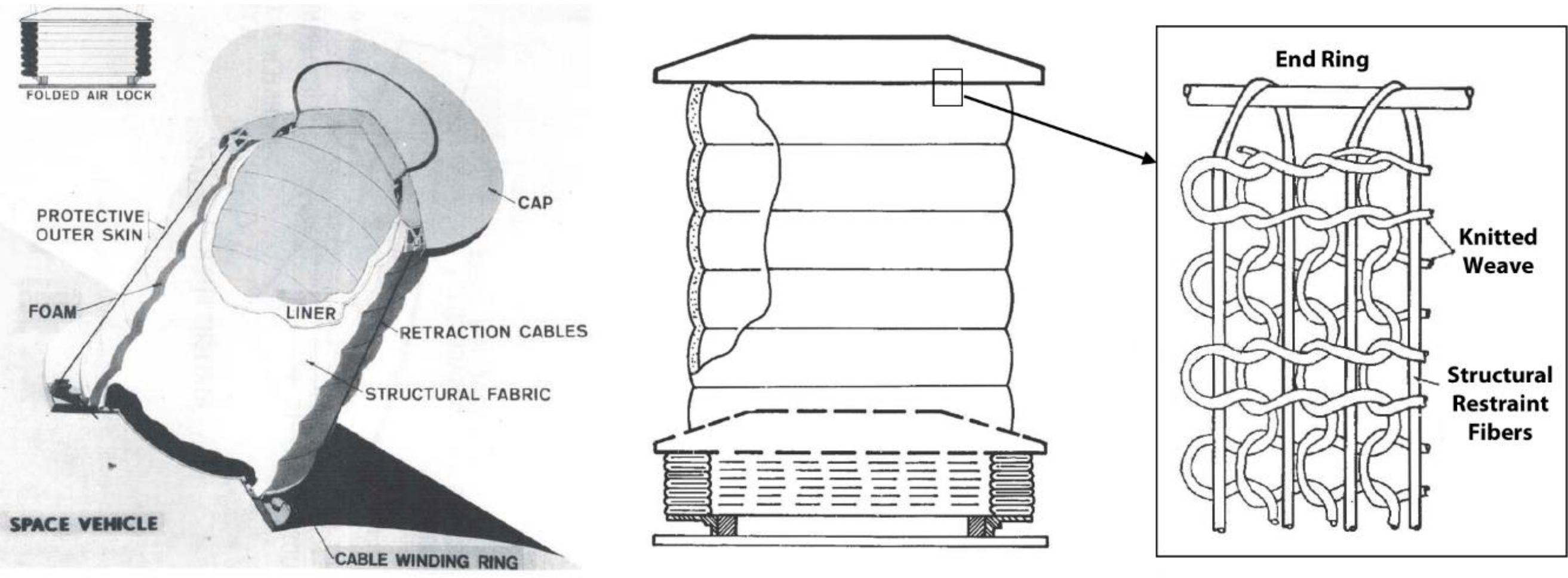

Lockheed PAL

NASA Patent

Volga

Goodyear D-21

Whittaker

NASA Patent$$
\text { NASA Patent }
$$

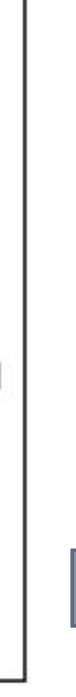$$
\text { Bigelow Pat. }
$$

Bigelow Pat DCIS MASH 


\section{HISTORY OF INFLATABLE AIRLOCK DEVELOPMENT}

\section{Advanced Inflatable Airlock (AIA)}

- Developed by Honeywell International, A\&P, FTL Design Engineering, Clemson University and NASA in 2001-2003

- Dimensions:

- Expanded: $8 \mathrm{ft}$ long $x 7 \mathrm{ft}$ wide; $226 \mathrm{ft}^{3}$ internal

- Hatch: $\mathbf{4 0}$ in diameter

- Built upon TransHAB technology for soft airlock to fit any platform or vehicle needing EVA capability with two crew members

- Design pressure of 14.7 psia, made of a nylon bladder, Vectran restraint layer, Nextel MMOD layer, MLI (multi-layer insulation) thermal blanket and Beta cloth outer layer

- Work focused on restraint layer, a single wide-angle braided Vectran tube, and a deployment/retraction system using linear actuators, air-beams, and pneumatic muscles

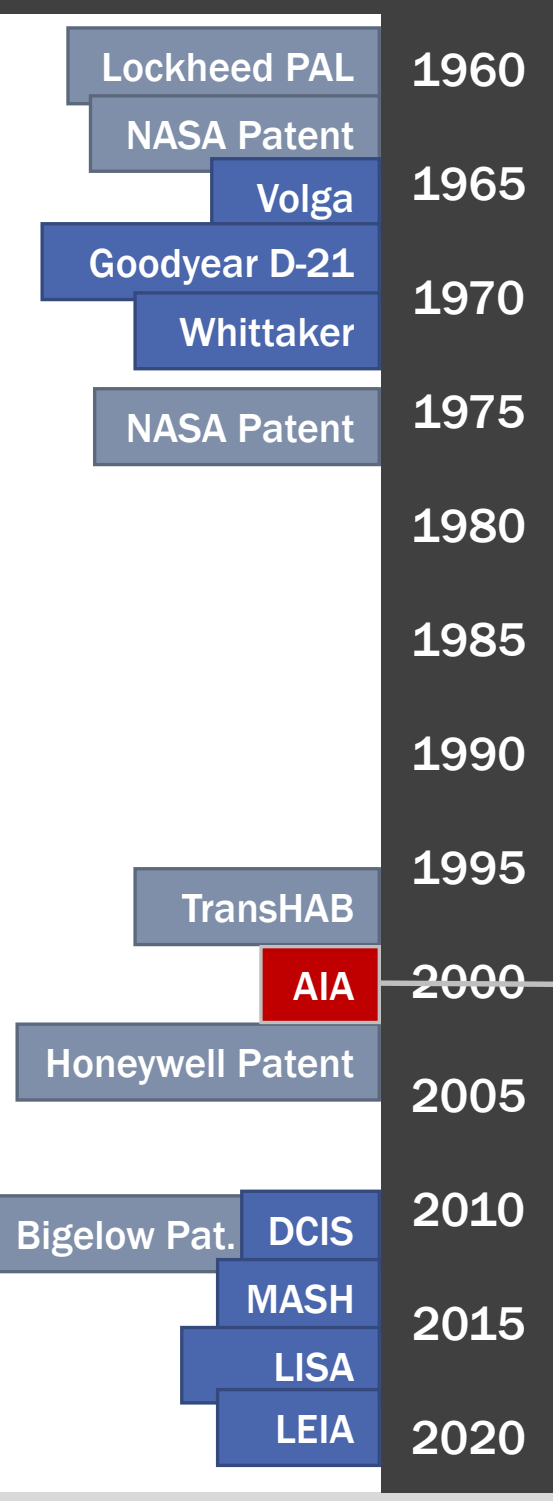




\section{HISTORY OF INFLATABLE AIRLOCK DEVELOPMENT}

Advanced Inflatable Airlock (AIA)
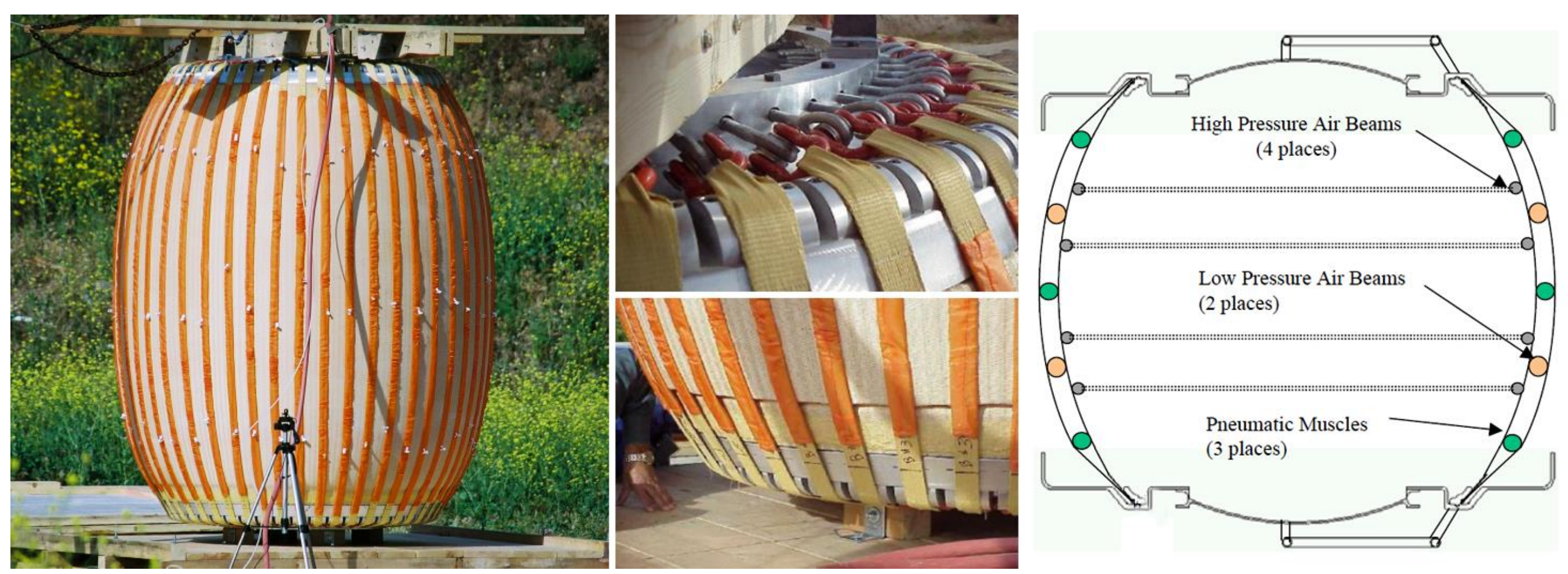

Bigelow Pat.
Lockheed PAL

NASA Patent

Volga

Goodyear D-21

Whittaker

NASA Patent

1970

1975

1980

1985

1990

1995

TransHAB

AIA 2000

Honeywell Patent

(

2005 2010 2015 LISA 


\section{HISTORY OF INFLATABLE AIRLOCK DEVELOPMENT}

\section{Dual-Chamber Hybrid Inflatable Suitlock (DCIS)}

- Developed by NASA JSC and JPL in 2011

- Dimensions:

- Expanded: $24.2 \mathrm{ft}$ long $x 9.2 \mathrm{ft}$ wide; $470.1 \mathrm{ft}^{3}$ internal

- Hatch: Surface door-type hatch

- Developed for the Lunar Surface Systems project under the Constellation Program

- Design pressure of 8.2 psia, made of three metallic bulkheads separated by fabric tunnels, creates a dual-chamber airlock that can be collapsed and moved on demand

- Operational testing was completed in a simulated surface mission with focus on suitport integration, dust mitigation, and a porch used for easier surface ingress/egress

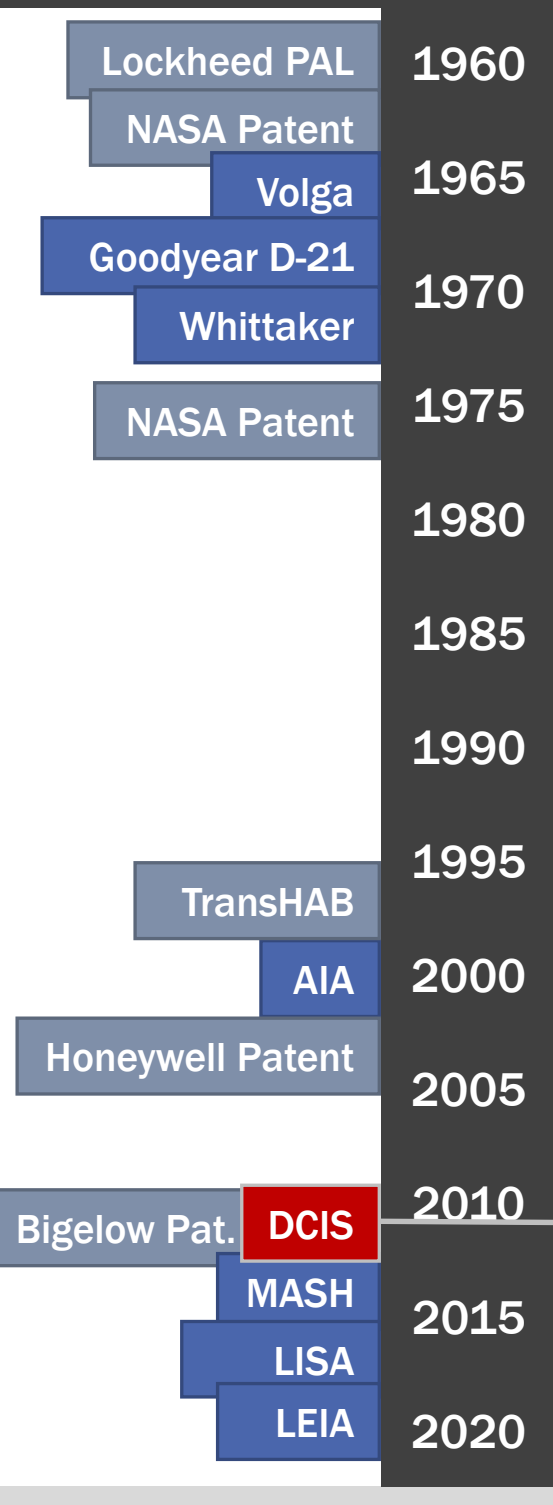




\section{HISTORY OF INFLATABLE AIRLOCK DEVELOPMENT}

\section{Dual-Chamber Hybrid Inflatable Suitlock (DCIS)}
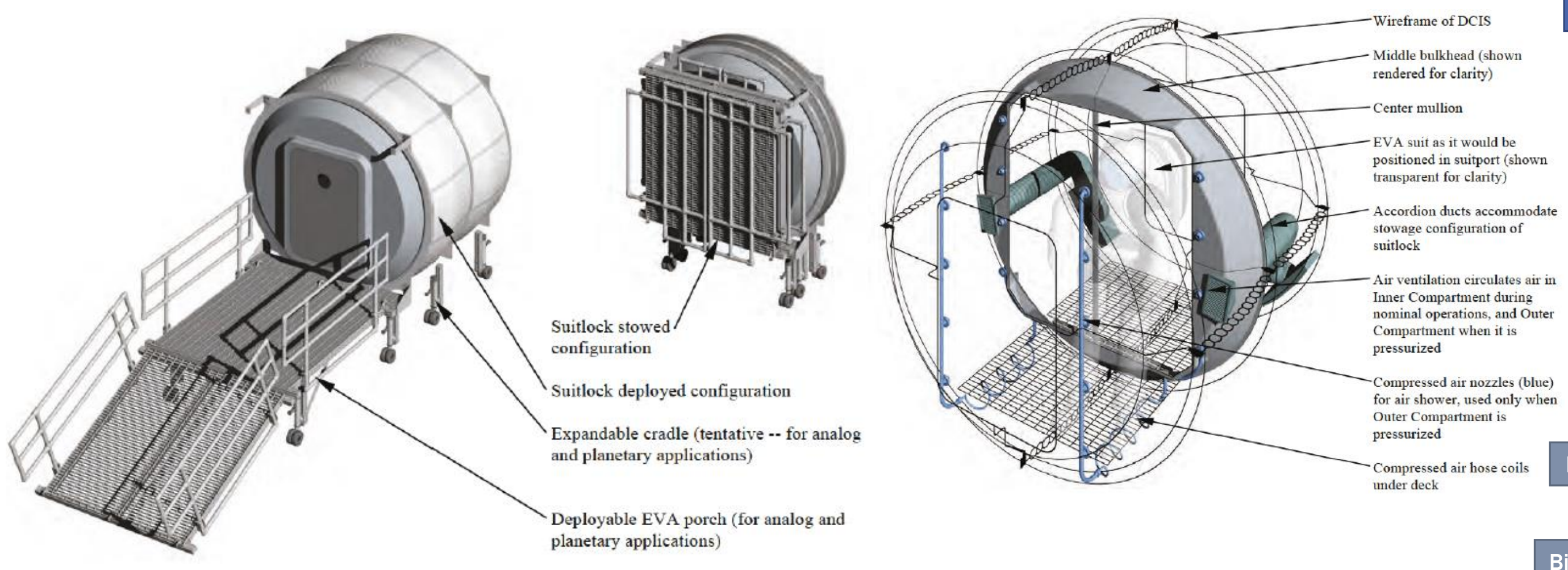
planetary applications)
1960 1965 1970 Goodyear Whittaker NASA Patent 1975 1980 1985 1990 1995 2005 2010 Bigelow Pat. DCIS MASH LISA 2015 


\section{HISTORY OF INFLATABLE AIRLOCK DEVELOPMENT}

\section{Minimalistic Advanced Soft Hatch (MASH)}

- Developed by NASA LaRC in 2014-2016

- Dimensions:

- Expanded: $14.7 \mathrm{ft}$ long x $6.5 \mathrm{ft}$ wide; $356 \mathrm{ft}^{3}$ internal

- Hatch: Integrated linear hatch

- Goal to significantly reduce weight of airlock hatch by integrating a soft hatch into a soft goods airlock structure

- Design pressure of 15.2 psia using a non-axisymmetric shape with lobed areas that provide low hoop stress zones, made of urethane coated nylon bladder, Vectran fabric and cordage restraint layer, designed for two crew members

- Structural testing completed on the non-axisymmetric shape and linear seal integration showed proof of concept for soft hatch in a unique design

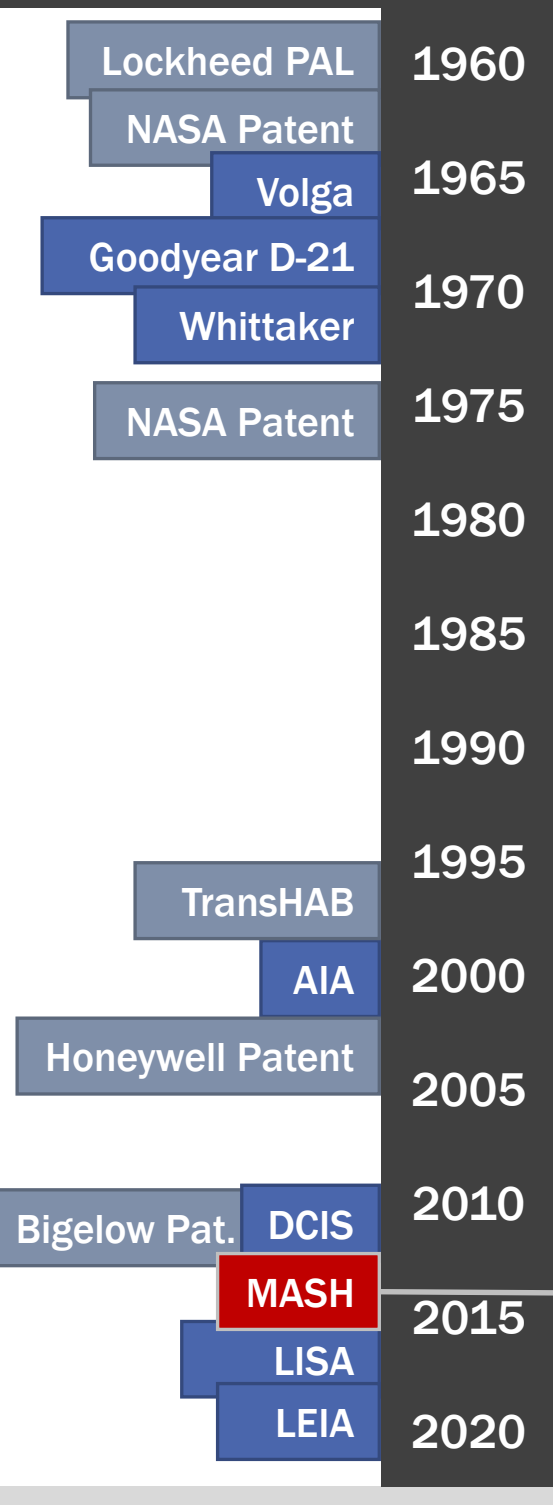




\section{HISTORY OF INFLATABLE AIRLOCK DEVELOPMENT}

\section{Minimalistic Advanced Soft Hatch (MASH)}

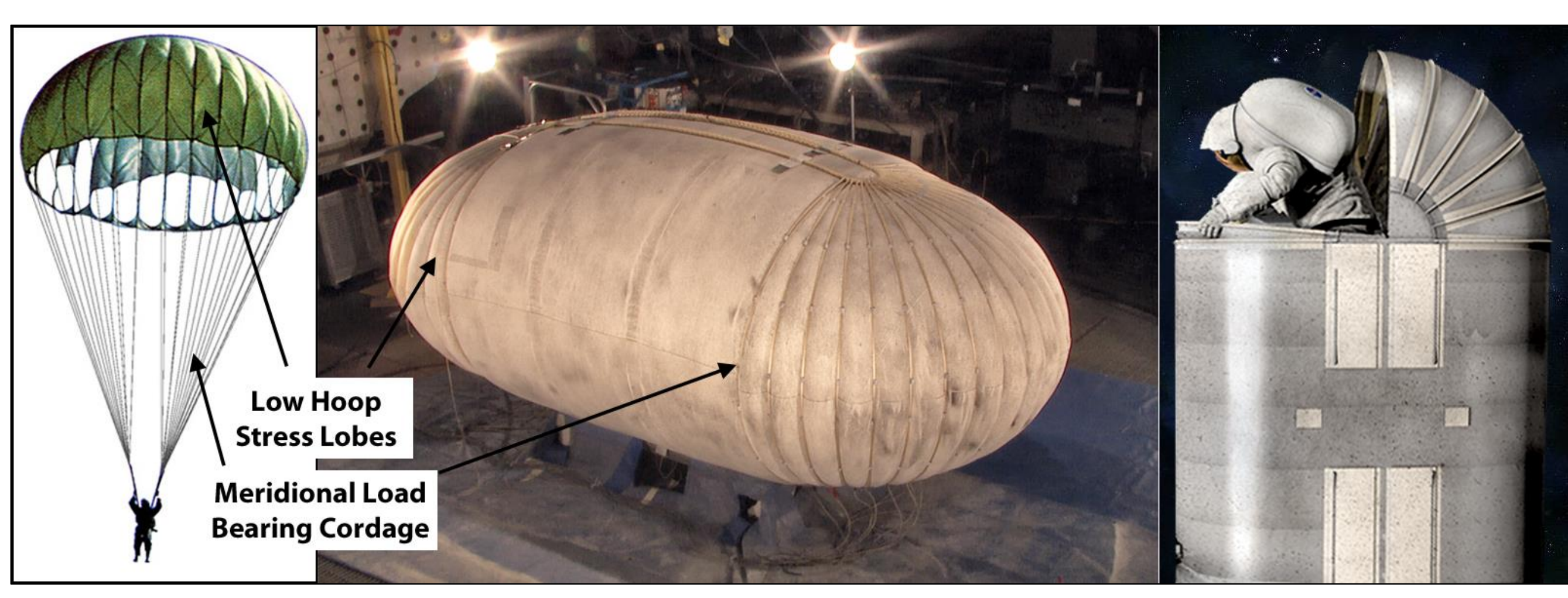

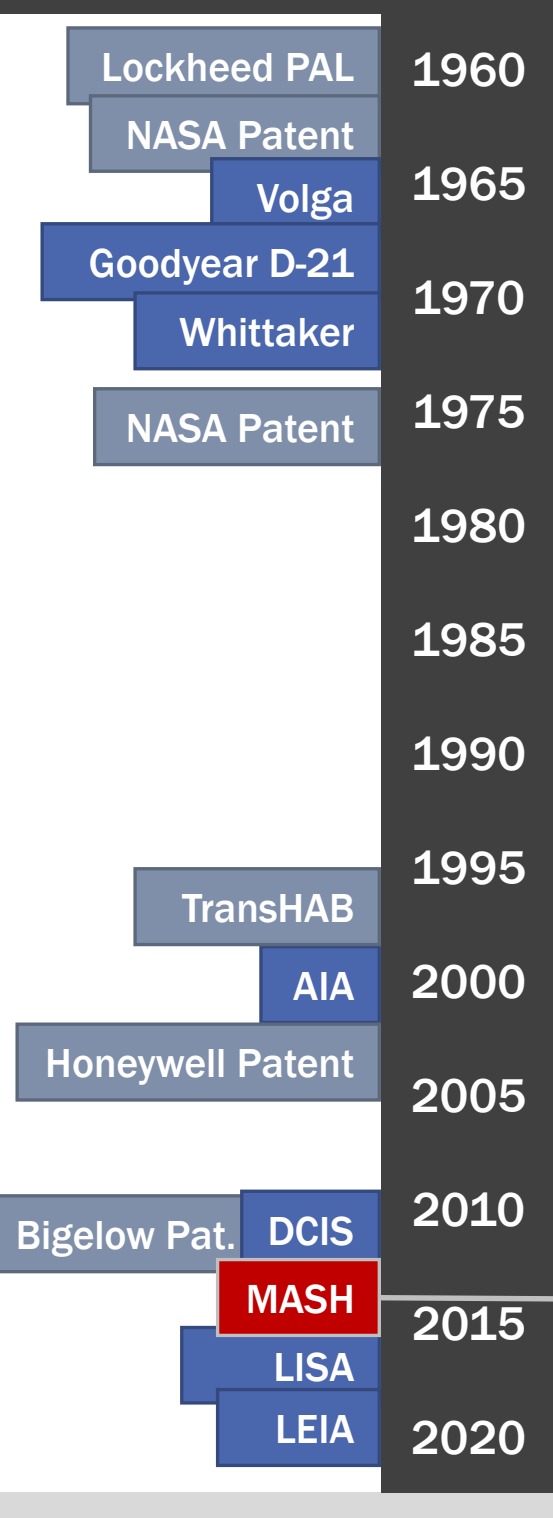




\section{HISTORY OF INFLATABLE AIRLOCK DEVELOPMENT}

\section{Lightweight Inflatable Structural Airlock (LISA)}

- Developed by Thin Red Line Aerospace and Computational Fluid Dynamics Research Company in 2016-2018

- Dimensions:

- Expanded: $5.9 \mathrm{ft}$ long $x 9.8 \mathrm{ft}$ wide; $327 \mathrm{ft}^{3}$ internal

- Hatch: Integrated linear hatch

- Developed under an SBIR with NASA

- Design pressure of 15.2 psia, utilizing a Ultra High Performance Vessel and proprietary linear seal, made of a urethane coated nylon bladder, Kevlar fabric and Vectran cordage, designed for two crew members

- Structural testing with an integrated linear seal was completed, advancing the state of the art and showing additional feasibility for a soft hatch airlock

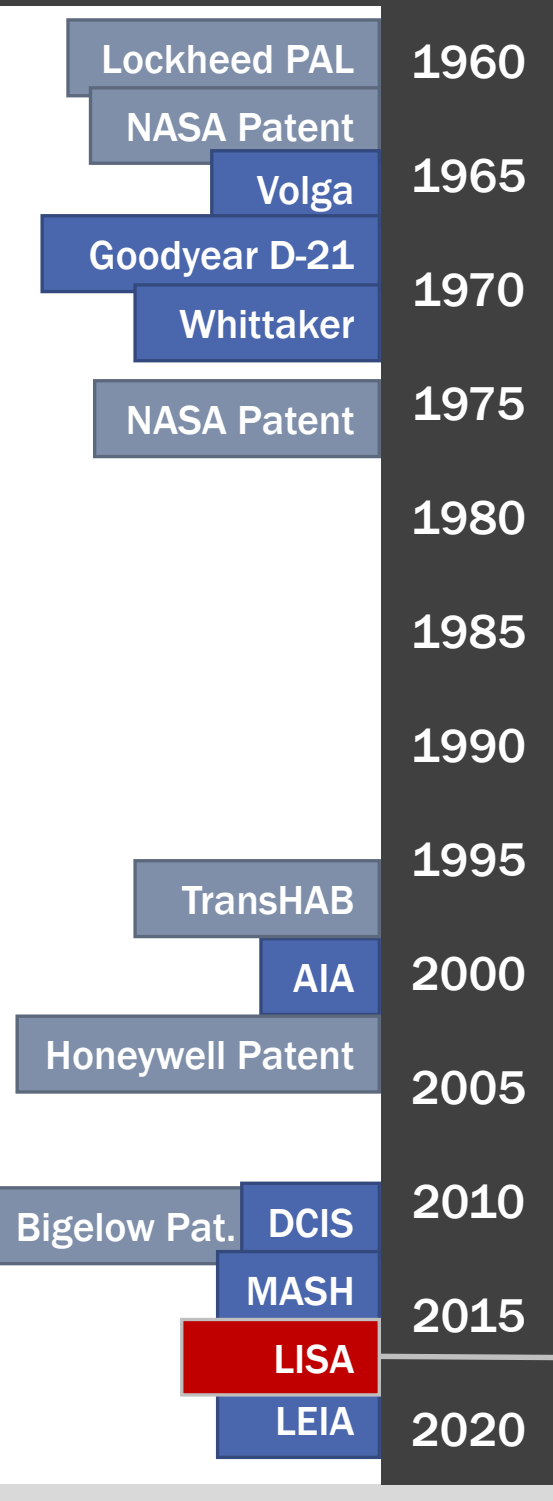




\section{HISTORY OF INFLATABLE AIRLOCK DEVELOPMENT}

\section{Lightweight Inflatable Structural Airlock (LISA)}
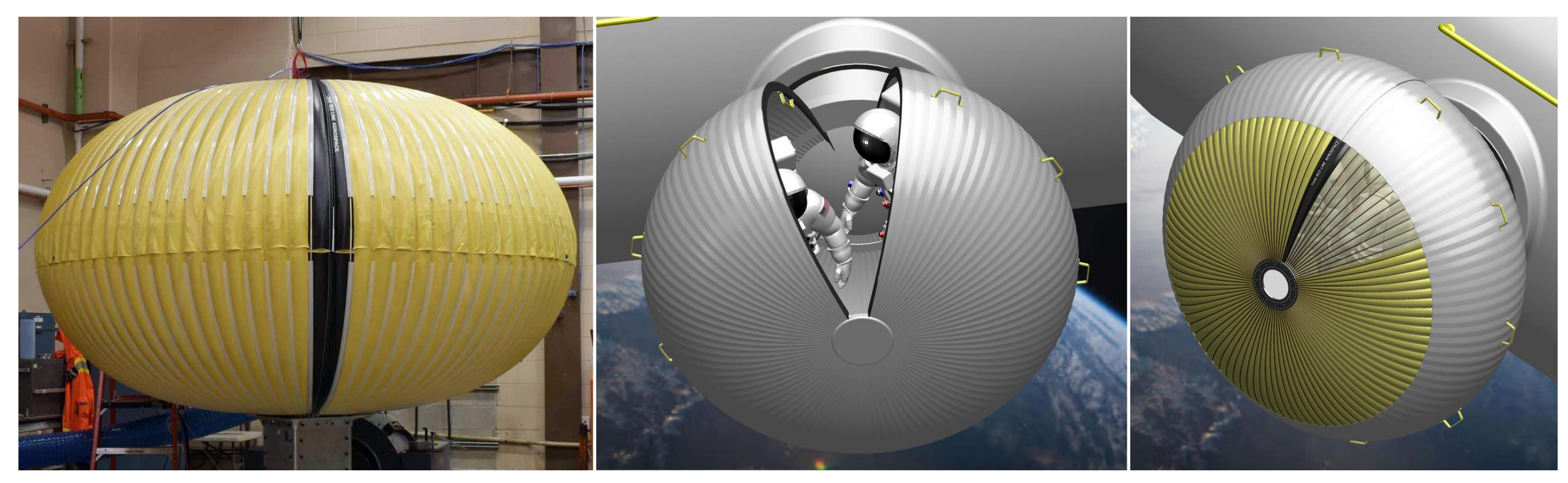

Lockheed PAL

NASA Patent

Volga

Goodyear D-21

Whittaker

1970

NASA Patent 1975

1980

1985

1990 


\section{HISTORY OF INFLATABLE AIRLOCK DEVELOPMENT}

\section{Lightweight External Inflatable Airlock (LEIA)}

- Developed by NASA JSC in 2017-2019

- Dimensions:

- Expanded: $13 \mathrm{ft}$ long $x 10.5 \mathrm{ft}$ wide; $565 \mathrm{ft}^{3}$ internal

- Hatch: 40 in diameter

- Design pressure of 14.7 psia, sized for two crew members, with focus on internal sub-structure and crew interfaces

- Iterated on two concepts for internal structure including an inflatable truss (made of Kevlar fabric) and an erectable truss (made of carbon fiber tubes)

- Conducted full scale mobility testing with micro-gravity simulation, developed soft handrails, and completed structural burst testing of an inflatable truss design

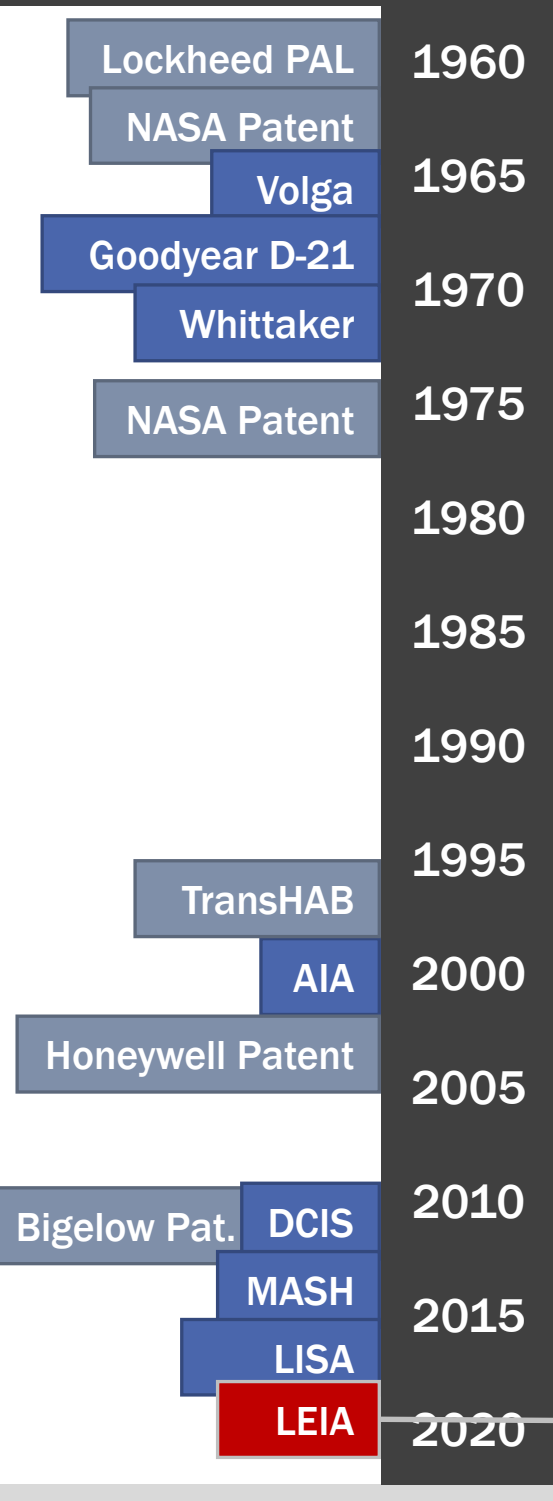




\section{HISTORY OF INFLATABLE AIRLOCK DEVELOPMENT}

\section{Lightweight External Inflatable Airlock (LEIA)}
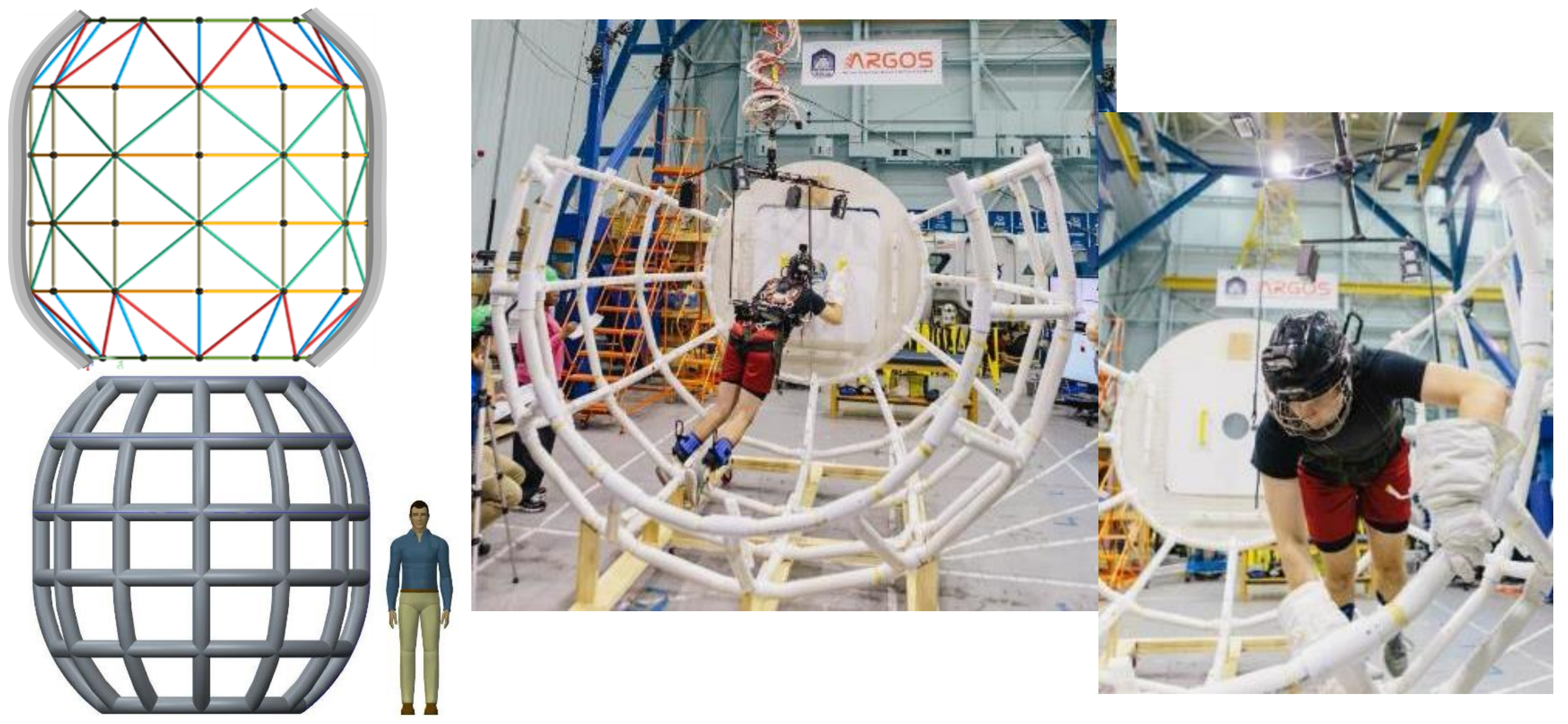

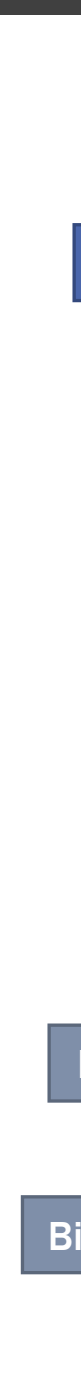

\begin{tabular}{|r} 
Lockheed PAL \\
NASA Patent \\
Volga
\end{tabular}

Goodyear D-21

Whittaker NASA Patent 1970 1975 1980 1985 1990 1995

TransHAB AIA 2000

Honeywell Patent 2005

Bigelow Pat. DCIS

\begin{tabular}{|r|} 
MASH \\
\hline LISA \\
\hline LEIA
\end{tabular} 2010 2015 2020 


\section{HISTORY OF INFLATABLE AIRLOCK DEVELOPMENT}

\section{Other Concepts and Patents}

1. NASA patent (1968) - single hatch with moveable airlock

2. NASA patent (1976) - flexible, deployable tunnel

3. Honeywell patent (2002) - deployable and retractable, flexible airlock

4. Lockheed Martin Portable Air Lock (PAL) (1963) - airlock concept shown in local newspaper

5. Bigelow Aerospace patent (2012) - inflatable airlock with exterior longerons

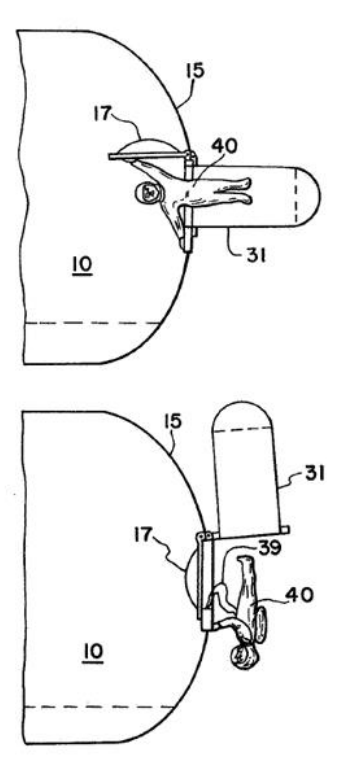

(1)
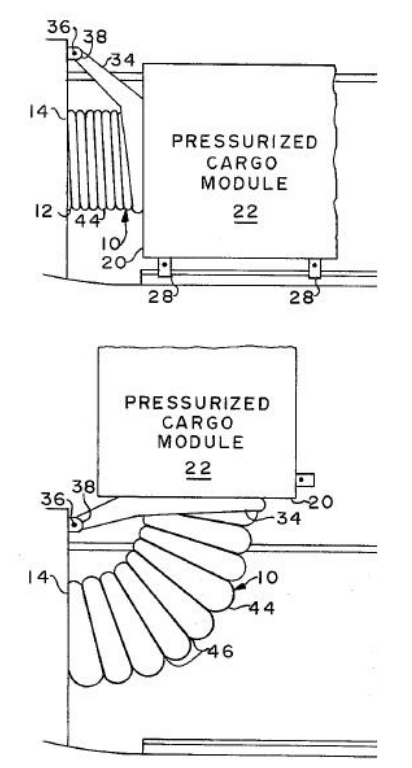

(2)

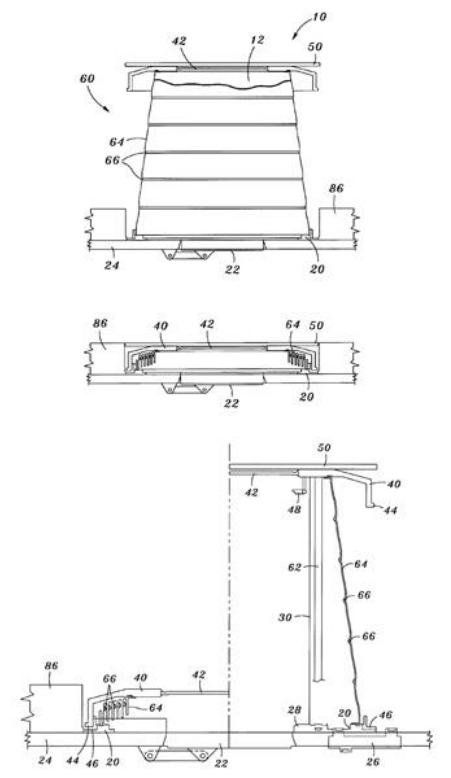

(3)

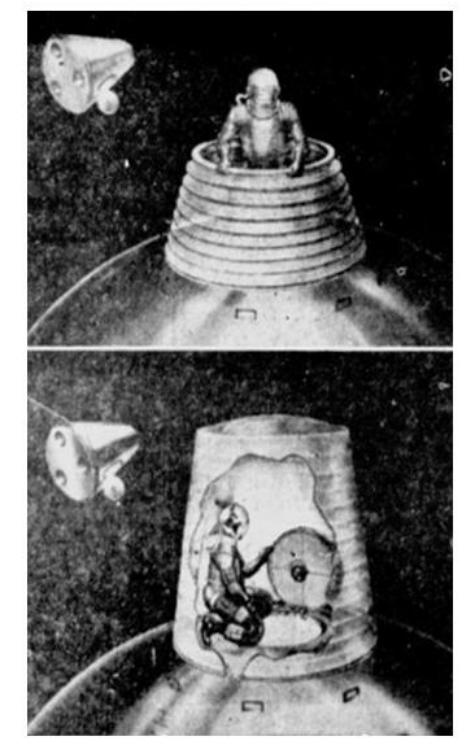

(4)

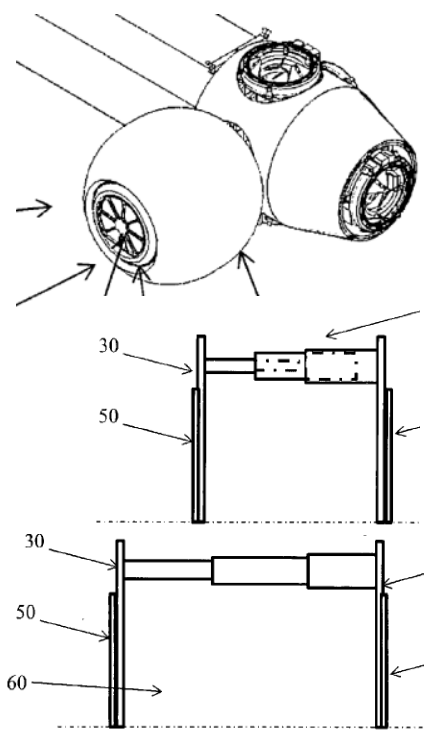

(5)

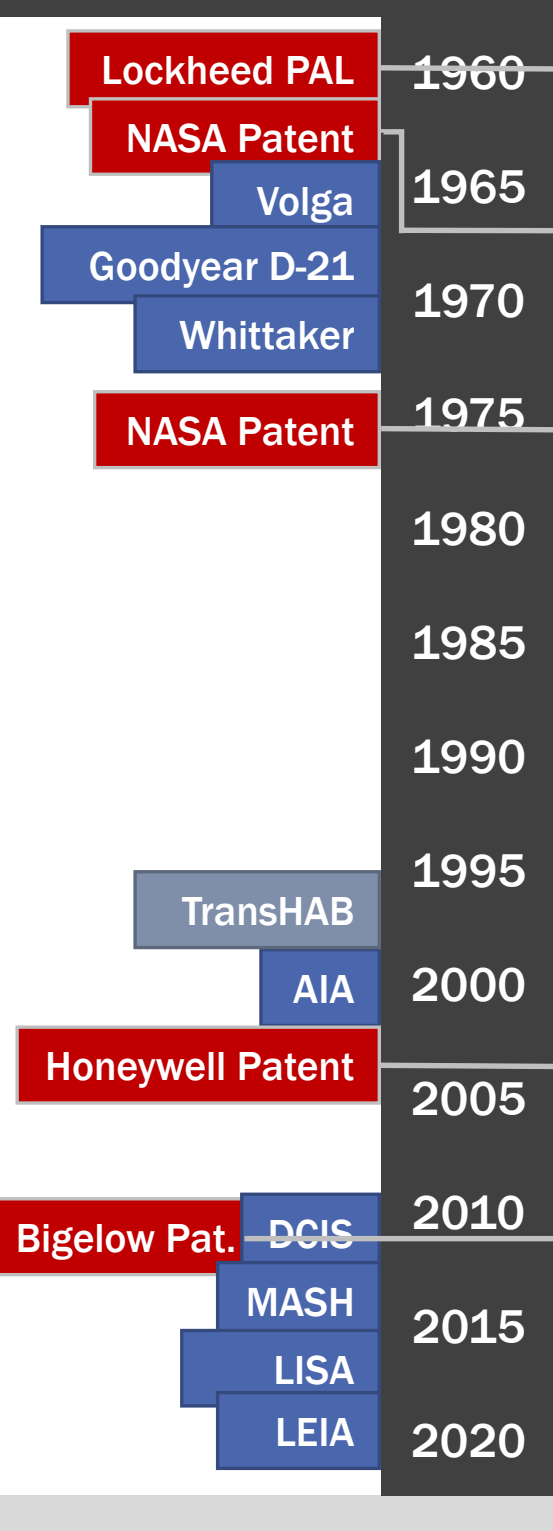

D. Litteken, NASA/JSC/ES2 | AIAA SPACE 2018 


\section{OUTLINE}

- Introduction

- History of Inflatable Airlock Development

- Design Considerations for Inflatable Airlocks

- Generic Airlock Considerations for Space Applications

- Inflatable Airlock Specific Considerations

- Conclusions and Future Work 


\section{GENERIC AIRLOCK CONSIDERATIONS}

- Dual vs Single Chamber Design

- ISS airlock uses a dual-chamber design

- Dual-chamber designs provide redundancy in the event of a failure, eliminate the need for hardware and electronics to be vacuum compatible, and minimize gas loss during a depress/repress cycle

- EVA community assumes future airlocks provide at least a secondary ingress capability as a backup option in the event of a failure

\section{- EV Hatch}

- Sized for crew members and payloads to pass through

- Typically EV hatches are pressure-assisted and inward opening

- Mounted on side of Crew Lock on ISS because of mobility issues with a suited crew member

- They can only use their hands/arms in front of their chest, so hatch placement and operation should be accommodating to these constraints

- Exploration guidelines designate a hatch should have $\geq 39$ in diameter opening 


\section{GENERIC AIRLOCK CONSIDERATIONS}

- Internal Volume

- Need volume for suit don/doff, suit maintenance, suit servicing equipment, logistics, tools, and payloads, which are typically housed in an Equipment Lock, but could be part of an integrated habitat or utility module

- The Crew Lock is often the smallest volume and only requires room for two suited crew members to be able to translate and operate the hatch

- Suit Interfaces

- Suits must be able to interface with the airlock to recharge consumables and be repaired/maintained

- Most of the servicing equipment is located in the Equipment Lock with a suit umbilical interface in the Crew Lock

- Handrails/Tethers

- Crew members translate through the airlock and onto the exterior of the spacecraft using handrails, handholds, and tether attach points

- Rigid translation aids are required for all expected translation paths, these are typically composed of metallic tubing that is designed for crew member tether and translation loads

- ISS translation aids use a specific cross-sectional shape that is designed to interface with the suit gloves and prevent inadvertent damage 


\section{OUTLINE}

- Introduction

- History of Inflatable Airlock Development

- Design Considerations for Inflatable Airlocks

- Generic Airlock Considerations for Space Applications

- Inflatable Airlock Specific Considerations

- Conclusions and Future Work 


\section{INFLATABLE AIRLOCK CONSIDERATIONS}

\section{- Dual vs Single Chamber Design}

- Inflatables achieve full structural capability once pressurized, so an inflatable Equipment Lock is not recommended because of the rigid equipment needed

- An inflatable Crew Lock, however, offers EVA capability in a small launch package

- Additionally, a dual-chamber design provides redundancy in the airlock

- Deployment/Folding

- Soft goods airlock should be packaged as small as possible on the ground, while not damaging the fabric layer

- Deployment method should provide initial expansion in a controlled and predictable manner using internal pressure and an internal/external deployment mechanism

\section{- Environmental Protection}

- Airlock must protect against the space environment, like a metallic airlock, but special considerations should be made for low temperature effects on polymer materials, radiation exposure to fabrics, and dust degradation on a surface airlock 


\section{INFLATABLE AIRLOCK CONSIDERATIONS}

\section{- EV Hatch}

- Soft hatches are still a low TRL and continue to be pursued by NASA and industry

- Integrating a traditional, rigid hatch into a soft goods airlock provides the most heritage and flight history for EVA ingress/egress

- Mobility/Handrails

- Crew members will require handholds, foot restraints, and tether attach points to move around the vehicle in micro-gravity

- Handholds could be made from soft goods and be foldable/expandable as long as they provide the required stiffness and rotational control

- Railing and attach points will also be required on surface missions to assist in crew mobility

\section{- Internal Secondary Structure}

- When the airlock is depressurized, a secondary structure is needed to maintain the module's stiffness and provide a framework for crew handholds and tethers

- This structure can be integrated into the fabric layers and be used on both the inside and the outside of the soft goods airlock 


\section{INFLATABLE AIRLOCK CONSIDERATIONS}

\begin{tabular}{|c|c|c|}
\hline Consideration & $\begin{array}{c}\text { In-Space } \\
\text { LEO/Interplanetary Vehicle }\end{array}$ & $\begin{array}{c}\text { Moon/Mars Surface } \\
\text { Surface Outpost/Mobile Vehicle }\end{array}$ \\
\hline Gravity & Micro-gravity & Reduced gravity \\
\hline Thermal & $\begin{array}{l}\text { LEO: Cyclic, day/night; } \\
\text { Interplanetary: Constant extreme cold }\end{array}$ & $\begin{array}{l}\text { Location dependent, Constant shadows, Long/regular day/night } \\
\text { cycles; Mars: Atmosphere and seasons; Moon: Abrupt day/night } \\
\text { transitions }\end{array}$ \\
\hline Radiation & LEO: Low risk; Interplanetary: Higher risk with GCR and SPE & $\begin{array}{l}\text { Higher risk with more common EVAs, longer distance from SPE } \\
\text { shelters, long term GCR }\end{array}$ \\
\hline Atmosphere & None, clean, hard vacuum & $\begin{array}{l}\text { Low to zero; Abrasive, magnetic, fine dust; Mars: High speed, low } \\
\text { pressure wind }\end{array}$ \\
\hline MMOD & $\begin{array}{l}\text { LEO: High risk (orbital debris); Interplanetary: Lower risk } \\
\text { (micrometeoroids) }\end{array}$ & Medium to low risk (long exposure) \\
\hline Crew Restraint & $\begin{array}{l}\text { Handholds, handrails, foot restraints; Tether attachments } \\
\text { required }\end{array}$ & Handrails, Rigid floor, Fewer mobility restraints \\
\hline Crew Movement & Cable and clip tether, Maneuvering unit & Self-powered, Walk, Hop, Climbing \\
\hline
\end{tabular}




\section{INFLATABLE AIRLOCK CONSIDERATIONS}

\begin{tabular}{|c|c|c|}
\hline \multirow{2}{*}{ Consideration } & In-Space & Moon/Mars Surface \\
\hline & LEO/Interplanetary Vehicle & Surface Outpost/Mobile Vehicle \\
\hline EVA Suits & $\begin{array}{l}\text { Limited range of motion, Fewer requirements than surface } \\
\text { suits }\end{array}$ & $\begin{array}{l}\text { Lightweight, Higher mobility, Robust to environment/dust, Need more } \\
\text { maintenance }\end{array}$ \\
\hline Consumables & $\begin{array}{l}\text { Possibility of venting air on each EVA, Primary vessel can } \\
\text { provide contingency air and egress volume }\end{array}$ & $\begin{array}{l}\text { Must recycle/recapture air, Mobile: Additional contingencies needed } \\
\text { due to risk }\end{array}$ \\
\hline Extra Equipment & EVA tools, Repair units, Upgrade supplies & $\begin{array}{l}\text { Outpost: EVA surface tools; Mobile: Equipment may need to be } \\
\text { accessed through external hatch }\end{array}$ \\
\hline EVA Frequency & Infrequent, Typically for repairs & Common, Potentially daily, Surface exploration \\
\hline Hatch & Circular or heritage D-shape with $\geq 39$ in diameter opening & $\begin{array}{l}\text { Taller and larger hatch for easier access and more common } \\
\text { entrance/exit in gravity }\end{array}$ \\
\hline Volume & $\begin{array}{l}\text { Min. volume/mass for consumables, Based on two EVA suited } \\
\text { crew members }\end{array}$ & $\begin{array}{l}\text { Min. volume/mass needed for planetary missions, Based on at least } \\
\text { two EVA suited crew members }\end{array}$ \\
\hline Pressure & Mission dependent, Typically 14.7 psia habitat pressure & $\begin{array}{l}\text { Mission dependent, Potentially } 8.2 \text { psia suitport and exploration } \\
\text { pressure }\end{array}$ \\
\hline
\end{tabular}




\section{INFLATABLE AIRLOCK CONSIDERATIONS}

\begin{tabular}{|c|c|c|}
\hline Consideration & In-Space & Moon/Mars Surface \\
\hline Deployment & One time deployment with secondary or habitat consumables & $\begin{array}{l}\text { Deployment with outpost consumables and retractability for } \\
\text { modularity and mobile use }\end{array}$ \\
\hline $\begin{array}{l}\text { Depressurized } \\
\text { Stability }\end{array}$ & $\begin{array}{l}\text { Needs lightweight deployable or erectable internal and } \\
\text { external structure including handrails and attachment points }\end{array}$ & $\begin{array}{l}\text { Needs lightweight deployable or erectable internal and external } \\
\text { structure including handrails, equipment stowage and floors }\end{array}$ \\
\hline Redundancy & $\begin{array}{l}\text { Dual or single chamber with multiple seal lines, Needs } \\
\text { contingency for failed hatch }\end{array}$ & $\begin{array}{l}\text { Outpost: Multiple elements and contingency airlocks available; } \\
\text { Mobile: Dual hatches }\end{array}$ \\
\hline Maintainability & $\begin{array}{l}\text { Vehicle relatively easy to access in micro-g during EVA with } \\
\text { translation aids, Long term missions should carry replacement } \\
\text { hardware and design for repairs }\end{array}$ & $\begin{array}{l}\text { Habitats harder to access with gravity, Long term missions should } \\
\text { carry replacement hardware and design for repairs, Dusty surface } \\
\text { environments require maintenance of seals and electronics }\end{array}$ \\
\hline Modularity & Mission dependent, Not required & $\begin{array}{l}\text { Mission dependent, Likely reusable/common elements for repair and } \\
\text { replace in space, Design for multi-use on Moon and Mars }\end{array}$ \\
\hline
\end{tabular}




\section{OUTLINE}

- Introduction

- History of Inflatable Airlock Development

- Design Considerations for Inflatable Airlocks

- Generic Airlock Considerations for Space Applications

- Inflatable Airlock Specific Considerations

- Conclusions and Future Work 


\section{CONCLUSIONS AND FUTUREWORK}

- A rigid Equipment Lock with an inflatable Crew Lock is the most feasible near-term integration approach for a Gateway airlock

- An inflatable Crew Lock provides several advantages over a metallic structure:

- Reduced launch volume can offer increased habitat volume

- Dual-chamber airlock offers contingency with little additional volume

- Secondary inflatable can be used to capture and reuse gas

- Soft goods materials have excellent impact resistance for MMOD protection

- Ability to deploy and retract and can be modular for multiple uses

- Developmental work continues at NASA to further develop:

- IVA/EVA outfitting and soft handholds

- Lightweight hatch developments

- Air circulation and ventilation integration

- Rigid hatch to soft goods seals

- Cold temperature materials testing

- Long term creep materials testing 


\section{QUESTIONS?}

\section{Doug Litteken}

NASA Johnson Space Center

Structural Engineering Division

douglas.litteken@nasa.gov 
1. NASA EVA Office, "Extravehicular Activity (EVA) Airlocks and Alternative Ingress/Egress Methods Document," EVA-EXP-0031, Houston, TX, 2018.

2. Portree, David S. F. and Robert C. Trevino, Walking to Olympus: An EVA Chronology, NASA History Office, Washington, DC, 1997.

3. Zak, A., "Vostok-2 Mission," http://www.russianspaceweb.com.

4. Hall, R. and D. J. Shayler, The Rocket Men - Vostok and Voskhod, The First Soviet Manned Spaceflights, Springer Praxis, Chichester, UK, 2001, pp. 236-248.

5. Tynan, C. I. Jr.; G., et al., "Expandable Structures Technology for Manned Space Applications," AAS/AIAA Variable Geometry and Expandable Structures Conference, Anaheim, CA, 1971, pp. 71-399.

6. Stimler, F. J., "System definition study of deployable, non-metallic space structures," Goodyear Aerospace Corporation, NASA-CR-171090, Akron, OH, 1984.

7. Manning, L., a. J. L., "Expandable Airlock Experiment (D-21) and the Skylab Mission," Goodyear Aerospace Corporation, AFAPL-TR-72-74, Akron, $\mathrm{OH}, 1972$.

8. Brink, N.O., et al, "Development and Evaluation of the Elastic Recovery Concept for Expandable Space Structures," NASA-CR-121, Washington, DC, 1964.

9. Berg, K. R., "Design and construction of an expandable airlock," Whittaker Corporation, NASA-CR-66709, San Diego, CA, 1968.

10. Williams, J. and N. O. Brink, "Development of an Expandable Airlock Utilizing the Elastic Recovery Principle," AFAPL TR-65-108, Washington, DC, 1965.

11. Brink, N.O., "Research on an Expandable Airlock Utilizing the Elastic Recovery Principle," Whittaker Corporation, NASA-CR-351, San Diego, CA, 1965.

12. de la Fuente, H., J. Raboin, Gary Spexarth, and Gerard Valle, "TransHab: NASA's Large-Scale Inflatable Spacecraft," AIAA Space Inflatables Forum, Atlanta, GA, 2000. 
13. Campbell, A., Barido, R., Knudsen, J., MacKnight, A., et al., "Advanced Inflatable Airlock System for EVA," International Conference On Environmental Systems, 2002.

14. Barido, R., MacKnight, A., Rodriguez, O., Heppel, P., et al., "Breadboard Development of the Advanced Inflatable Airlock System for EVA," International Conference On Environmental Systems, 2003.

15. Howe, Scott A.; Kennedy, Kriss; et al., "A Dual-Chamber Hybrid Inflatable Suitlock (DCIS) for Planetary Surfaces or Deep Space," AIAA International Conference on Environmental Systems, Portland, OR, 2011.

16. Doggett, William R.; Jones, Thomas C.; et al., "Non-Axisymmetric Inflatable Pressure Structure (NAIPS) Concept that Enables Mass Efficient Packageable Pressure Vessels with Sealable Openings," NASA Langley Research Center, Hampton, VA, 2016.

17. Shariff, K., M. Schaefbauer, W. R. Doggett, J. Warren, and T. C. Jones, "Inflatable Airlock: Seaming Techniques of Highly Loaded Fabrics," AIAA SciTech Forum, Gaylord, TX, 2017.

18. Jones, Thomas C.; Doggett, William R.; et al., "Non-Axisymmetric Inflatable Pressure Structure (NAIPS) Full-Scale Pressure Test," AIAA SciTech Forum, Gaylord, TX, 2017.

19. Judd, J. H., "Spacecraft Airlock," US Patent No. 3,386,685, 1968.

20. Fletcher, J. C., "Deployable Flexible Tunnel," US Patent No. 3,952,976, 1976.

21. Patel, V. P., "Deployable Flexible Airlock," US Patent No. 6,499,697, 2002.

22. The Rochester Sentinel, October 4, 1984, "The Astronaut's PAL,"

https://news.google.com/newspapers?id=kiRjAAAAIBAJ\&sjid=oXMNAAAAIBAJ\&pg=4200,3569322\&hl=en.

23. Ingham, Jay, "Inflatable Airlock," US Patent Application No. 2012/0318,926/A1, June 14, 2012.

24. NASA EVA Office, "Exploration EVA Systems Concept of Operations," EVA-EXP-042, Houston, TX, 2017.

25. NASA, "Human Integration Design Handbook (HIDH)," NASA/SP-2010-3407/REV1, Washington, DC, 2014. 